\title{
New Directions in Soviet Planned Bibliography
}

By THOMAS J. WHITBY

$\mathrm{T}$

The Communist Party congresses have always been calls to action for the various segments of Soviet society. The special Twenty-First Congress early in 1959 was no exception. It gave emphasis in its resolutions to the further development of education, science, and culture (a broad area including the theater, the cinema, the press, museums, and libraries). Implementation of the Congress' resolutions, apparently, is to be carried out with assistance from bibliography, that basic activity which gives support to all fields of learning.

Evidence for this comes from the reports in Sovetskaya Bibliografiya ${ }^{1}$ and Bibliotekar',2 Soviet journals devoted to bibliography and library science respectively, of the Moscow conference on bibliography held February 9-12, 1959 under the joint auspices of the Lenin Library in Moscow, the Saltykov-Shchedrin State Public Library in Leningrad, and the Moscow State Library Institute. It is obvious from these reports that in the seven-year period 1959-1965 the West will witness an all-out effort in Soviet bibliography. The topics on the agenda of the conference indicate the comprehensive view the Soviets are taking of bibliography as a support for national aspirations. The areas considered are current bibliography, retrospective bibliography, selected bibliography, regional bibliography, bibliography of bibliography, and bio-bibliography. A closer look at the salient points made at the conference under several of these broad, traditional divisions of bibliogra-

1 Z. L. Fradkina, "Konferentsiya po voprosam bibliografi," "Sovetskaya Bibliografiya, LIV (1959). 104-10. 2 Fradkina, "Konferentsiya po voprosam bibliografii," 2 Fradkina, "Konferentsiya po
Bibliotekar", V (1959), 57-58.
Mr. Whitby is Senior Subject Cataloger, Library of Congress.

phy may reveal what the Russians hope to achieve.

Current Bibliography. Insofar as national bibliography as a division of current bibliography is concerned, the Knizhnaya Letopis' (Book Annals) and its sister organs devoted to the listing of periodical titles, maps, prints, music scores, etc., completely cover all current publishing. However, the Russians consider indexing as an integral part of their system of national bibliography, and here there is still room for improvement. For example, the Soviet index, Letopis' Zhurnal'nykh Statey (Annals of Periodical Articles), indexes only a partial selection of periodicals. At the conference the proposal was made to enlarge the scope of this index by including additional periodical material. This weekly index is general and not cumulative; with its present coverage, it cannot stand comparison with our own H. W. Wilson Company indexes. The gap in periodical coverage may be explained, on the one hand, by the Soviets' preference for printed cards for periodical articles, which they assemble in library catalogs, and, on the other hand, by the emergence in recent years of high quality abstracting services. The gap, however, is now to be closed with a bigger, better periodical index.

The State Public Science and Technical Library of the USSR (Gosudarstvennaya Publichnaya Nauchno-tekhnicheskaya Biblioteka SSSR) was also asked to 
renew issuance of the Novosti Tekhnicheskoy Literatury (Technical Literature News), an annotated bibliography for current Soviet technical literature that ceased publication in 1953. In view of the scope of the several series of Referativnyi Zhurnal (Abstract Journal) of the All-Union Institute of Scientific and Technical Information, which abstracts on a current basis both foreign and domestic scientific and technical literature, it is not apparent why the proposal was made at this time. A possible explanation is that it is now expedient to abstract separately the foreign literature and the domestic literature. A revitalized Technical Literature News in the form of a series of abstracts would be in line with the long-standing Soviet practice of separating the foreign from the domestic, so characteristic of the way their libraries, bookstores, catalogs, and bibliographies are organized. Such a divorce in the Referativnyi Zhurnal would also provide the recently upgraded State Public Science and Technical Library with the opportunity to launch a first-rate publication of its own, thereby enhancing its reputation in the eyes of Soviet librarians and bibliographers. A closely related matter is the conference resolution asking the All-Union Institute of Scientific and Technical Information to publish catalog cards for the foreign articles that it abstracts.

Selected Bibliography. The Lenin State Library of the USSR and the Saltykov-Shchedrin State Public Library in Leningrad have always been the leaders in the field of selected, or recommended, bibliography. For the future the congress passed a resolution that these two large libraries adopt a unified plan for the issuance of bibliographies according to user interest in the fields of self-education, improvement of job qualifications, and the popularization of science.

The State Public Science and Technical Library of the USSR was urged to coordinate the work of its network of technical libraries in the creation of selected bibliographies for workers in the various trades (professiy).

This special branch of bibliography, which incidentally is a de-emphasized activity in the United States, is the Soviet way of bringing bibliography to the attention of the average citizen. Imagine putting tailor-made bibliographies into the hands of the skilled and semi-skilled workmen and farmers, as well as the engineers and other professional groups. The Soviets expect a degree of literacy on the part of the workingman of such a calibre that he will be interested in reading the literature in his own special field. Therefore, any system of informing the workman about the relevant literature is highly regarded by the Soviets. The impact of this approach on the dissemination of knowledge is difficult to evaluate, but the Soviets are convinced that it is an effective factor in their plans for further industrialization.

Regional Bibliography. It is in this area that the most telling growth will take place in the seven-year plan for bibliography. The resolution of the conference speaks eloquently for the intensive development to be expected in this area. It reads as follows: "In the field of regional bibliography it is deemed necessary: to prepare plans in each oblast, kray, and republic for the development of regional bibliography; to provide in each oblast, kray, and republic for the regular issuance of a bulletin of current regional bibliography; to compile and publish regional retrospective bibliographies in economics, natural conditions and resources, as well as topical bibliographies on current problems relating to the tasks set forth at the 21 st Congress of the Communist Party of the Soviet Union; to unite the efforts of libraries in the compilation of regional bibliographies by geographic region (the Urals, the North, Siberia, etc.); to involve the All-Union Geographical Society and other societies and institutions in the 
compilation of regional bibliographies; to ask the Ministry of Culture of the RSFSR and the ministries of culture of the union republics to work on the problem of the staff duties of a regional bibliographer in each republic, oblast, and kray library, and also to hasten the solution of the problem of the creation of zonal libraries; to ask the Ministry of Culture of the USSR to reach quickly a solution to the problem of local legal deposit; to organize a special section for the coordination and technical guidance of the work on the creation of a regional bibliography within the department of library science and bibliography of the Lenin State Library of the USSR." 3

The program outlined above in the field of regional bibliography is the most comprehensive and far-reaching plan for the exploitation of current and past literature that has been announced by the Soviets in recent years. It means that each geographic area and each politicaladministrative division through the regional (oblast) level will probably have its own bibliography. A program on a comparable basis in the United States would have to specify a bibliography for New England, one for the state of Maine, and one for Androscoggin County. Such bibliographies, listing all works, regardless of form, that pertain to given geographic units, will undoubtedly exert an important influence on future research undertaken locally. It is well known that many facets of Soviet life are organized on a geographic basis, so that the development of bibliography along geographic lines has real meaning. It is possible that there is a direct relationship between the organization of the state and that of bibliography.

The feasibility of such a program in the Soviet Union can be readily seen if one recalls that the Soviets have a complete and current national bibliography and a system of legal deposit that has en-

3 Fradkina. "Konferentsiya po voprosam bibliografii," Sovetskaya Bibliografiya, 108-109. riched numerous large research libraries throughout the country. For many years now the All-Union Book Chamber has been receiving, listing, and distributing the entire published product of the Soviet Union. In the union republics similar systems have been in use for almost as long. The beneficiaries of the system of distribution have been the large research libraries of the country. With such a highly developed bibliographic organization it requires no great imaginative effort on the part of the Soviets today to be able to exploit this legacy on a local and regional basis.

Bibliography of Bibliography. To keep track of published bibliographies in their own land the Soviets have relied principally upon the Bibliografiya Sovetskoy Bibliografii (Bibliography of Soviet Bibliography), published annually by the All-Union Book Chamber. The conference requested that this field be strengthened by giving more attention to the bibliography of foreign bibliography and to the work on the bibliography of bibliography in the union republics.

One final resolution of the conference pertained to the establishment of a professional association of librarians and bibliographers for the entire USSR. Certainly the importance of the bibliographer, already a much respected member of the scholarly community in the USSR, will be enhanced by the bibliographic seven-year plan just getting under way. The formation of a professional association of librarians and bibliographers in the Soviet Union appears, to the outsider at least, to be a rather necessary step in a situation where heretofore there has been no official body that could speak for all librarians, much less for all bibliographers. The newly formed Council on Library Problems (Sovet po voprosam bibliotechnoy raboty) is working out the details for the proposed society. In a land where the librarian and bibliographer until now could expect no more than membership 
in a cultural trade union, the formation of a professional society undoubtedly comes as a welcome development.

The Council on Library Problems was established early in 1959 within the framework of the Ministry of Culture of the USSR. It held its first meeting in March. From published accounts it is apparent that the Council is to function as a coordinating and planning body for all Soviet libraries and bibliographic institutions. At the first meeting it formed sections for public libraries, research libraries, children's libraries, and technical libraries. It also established commissions on library buildings and equipment, international relations, bibliography, and organization. One of its current undertakings, as indicated above, consists in getting a professional library association constituted. Another is the working out in detail of a seven-year plan for the large research libraries, the book chambers, and the library institutes. It is no exaggeration to say that the Council will act as a catalyst, appreciably accelerating the development of library and bibliographic work in the Soviet Union.

It is apparent that the bibliographic program summarily described here signifies a broad attack on the major areas of bibliography as they relate to the seven-year plan for economic, cultural, and ideological development in the Soviet Union. From the scope of the program it is also apparent that the Soviets have no misgivings or doubts about the value of various types of bibliography or the uses to which they may be put. They fully believe that bibliography can help them in the attainment of national goals. They know what they want from bibliography and they are taking the most direct steps to developed programs to get it.

\section{Guaranteeing the Continuity-the Library}

The celebrated definition of a college by Mark Hopkins lacked one basic element-the library. In many institutions it is very low on the totem pole-below the student union, athletic field, gymnasium, and other accepted facilities. Colleges and universities will invest great sums in expensive scientific and technological equipment, all of which may be necessary, but will not meet satisfactorily the needs of that branch of the institution which is extremely close to its reason for existence and which is perhaps the best single means of guaranteeing the continuity between classroom and postcollegiate culture. . . .

The "bad boy" of contemporary criticism, Prof. John Ciardi of Rutgers University, banged his fist squarely on the problem in his recent address at Miami University. "At the heart of every college is one essential and indispensable buildingthe library," he stated. "If our students could use the library without supervision, you'd need only one man to run a college-a janitor to keep the place swept up."

A first-rate library and the implantation of inspiration in students to use it to its fullest extent will surely help solve some of the persistent problems in American higher education. The triple combination of teacher, student, and library is an essential element in the fulfillment of the function of the university. Most of the others are peripheral, irrelevant, and even deleterious.-William W. Brickman in "The Library and Higher Education," School and Society, LXXXVII (1959), 348. 